\title{
The Political Economy of Food Subsidy in India
}

\author{
ASHOK KOTWAL, MILIND MURUGKAR \\ AND BHARAT RAMASWAMI
}

\begin{abstract}
Indian parliament is getting ready to debate the National Food Security Bill that would be the single biggest poverty alleviation programme, costing about 1.5 per cent of India's gross domestic product. There has been a fierce debate leading up to the drafting of the bill and subsequent modifications. This article first points out the salient features of the Indian economy to give context to assess the current debate. In particular, it gives a detailed picture of the grain market in India and the important role played in it by the central government. It traces the path of the bill from its genesis through the subsequent debate and political process. The article identifies the key players in the debate and the role they have played in shaping the provisions in the latest draft of the bill. At the end, the authors speculate about likely food security outcomes in India.
\end{abstract}

Keywords: food subsidy, in-kind transfers, cash transfers, corruption, information technology

\section{Introduction}

India, a country known for its sharp contrasts, is growing at 8 per cent per year even in this post financial crisis period while poverty has declined only modestly. Over the two decades from 1983 to 2004, the head count measure of poverty dropped less than 20 percentage points (from 45 per cent to 27 per cent). More alarmingly, the population subsisting under twice the Indian poverty line (approximately US\$2 a day at 1999 prices) barely came down, from 86 per cent to 80 per cent (Kotwal, Ramaswami \& Wadhwa 2011). As the aspirations rise among the top economic tiers of the society, so does the level of frustration of those left behind. The governments at both the central and state level therefore feel compelled to try out different palliatives to poverty. The two largest poverty alleviation programmes of the central government 
are the National Food Security Bill and the Mahatma Gandhi National Rural Employment Guarantee Act. What is unique about these two initiatives is that they confer on each Indian household legal rights to food and employment - an ambitious step for a country as large and poor as India. Both measures can be regarded as different means of income transfer to the poor. This paper will analyze specifically the debate over the proposed National Food Security Bill as well as the political economy of the process that is shaping it. The bill has been introduced in the parliament and a parliamentary standing committee has been set up to receive feedback from all interested parties. The bill is likely to be debated during the monsoon session (2012) of the parliament and this is an opportune time to undertake such an analysis.

\section{Salient Features of the Course of Development in India}

To be able to judge the merits of various arguments in the debate and to appreciate the political economy underlying them, it is important to note a few salient features of the structure of the Indian economy as well as of the growth path it has travelled over the last three decades.

\section{Informal Economy}

First, almost 92 per cent of India's labour force makes a living in the informal sector that is comprised of small units of one to nine people. Twenty-six per cent of India's population is still illiterate and most of those who work in the informal sector have an educational level below eighth grade. Many of them have no school certificate, no bank account, no record of house ownership, no tax records or any official identity cards that would give them a direct connection with the government administration. Any poverty alleviation scheme is vulnerable to corruption as the poor have very weak political power. This leaves scope for intermediaries to siphon off funds targeted to the poor. It is unrealistic to expect sustained political pressure from this politically weak section of the society for efficient delivery of welfare. It is instructive to note that in 2004-2005, the income transfer to the poor accounted for only 10 per cent of the cost of food subsidies (Jha \& Ramaswami 2012).

\section{Uneven Growth}

Second, the rapid growth of the last three decades has been spearheaded by a few skill-intensive sectors such as software and business services, which unfortunately absorb little unskilled labour directly. There has 
been some trickle down through increased demand in sectors such as trade, transportation and construction. But employment for low-skilled workers has grown at a much slower rate than income, exacerbating the existing inequalities. (Eswaran, Kotwal, Ramaswami \& Wadhwa 2009). Since the growth process itself is not resulting in a rapid decline in poverty, the case for well-funded poverty alleviation programmes meets very little direct political resistance. ${ }^{1}$ In fact, the expenditure on poverty programmes can be regarded as a side payment from the rich to the poor to compensate partly for unequal growth that could create political unrest. The debate is therefore not about whether to fund income transfers to the poor but rather how to do it.

\section{Transfers to the Poor to Build Human Capital}

It is easy to see that the demographic dividend that India is expected to reap over the next few decades will not amount to much if the new generation is malnourished and undereducated; the economic future very much depends upon the human capital of the next generation. All political parties therefore accept the need for efforts to boost the nutritional and educational levels of the poor.

In fact, the food share of total consumption expenditures has declined since 1983 for all income groups in India. Nutritional levels (intake of calories, protein and micro-nutrients) have also dropped for all income groups between 1983 and 2004 (Paul 2011). Some people have seen this as a sign of impoverishment of the masses (Patnaik 2007, 2010) while others (Deaton \& Dreze 2009; Banerjee \& Duflo 2011) have tried to explain it in terms of consumer choices in the context of environmental changes (e.g., fewer calories needed as a result of growth in infrastructure). There may be legitimate reasons for a decline in calorie intake but a fall in nutritional standards is indeed of concern.

One practical problem here is that it is exceedingly difficult for society to make sure that the poor use the aid they receive for the intended purpose of nutrition. For example, if food is sold at subsidized prices, it is quite possible that they spend the savings thus incurred on something other than food. This need not be a frivolous expenditure. Every household has its own priorities and if a particular household decides to buy a cell phone instead of improving their food basket, it may very well be that they feel a stronger need for that phone than for more calories. In short, there is a limit to the control that a society can exercise over individual lives (Banerjee \& Duflo 2007, 2011). 


\section{Farmers' Welfare as a Consideration}

Governments all over the world worry not just about the consumption of the poor but also about 'food security' for the country, which includes incentives to food producers. Even the proposed bill is named the National Food Security Bill. Any intervention in the food market must therefore safeguard the interests of the consumers as well as the producers of food. In India, consumers have always been subsidized partly at the expense of farmers through policies such as levies for sugar and rice and periodic export bans on rice and wheat. Farmers have gradually acquired greater voice and we see this reflected in a steady rise in the Minimum Support Price (MSP) for food grains. Yet, there continues to be an export ban on rice and the domestic price of rice is kept much lower than the international price. In addition, a significant part of the informal sector is agriculture. Many of the poor are thus farmers and if policy-makers try to subsidize poor consumers by forcing the market price down, it would not have the impact on poverty they desired. Food price suppression hurts the farmers with large surpluses to sell. While these are not likely to be poor, a depressed agricultural economy offers weak demand for the only asset the rural poor have-their physical labour.

\section{Public Distribution System}

The Public Distribution System (PDS), a remnant of the rationing system from the Second World War years, is the present vehicle for delivering food subsidies in India. The Food Corporation of India (FCI), set up in 1965 as a government agency to procure food grains, ${ }^{2}$ has the responsibility to procure food grains and to distribute them to state governments for the ultimate distribution to consumers through select retail outlets known as 'fair price shops'. Until 1997, the PDS coverage was universal but since then the PDS has targeted certain categories of households, labelled 'Above Poverty Line' (APL), 'Below Poverty Line' (BPL) and 'Poorest of the Poor' (POP). Eligible beneficiaries receive 35 $\mathrm{kg}$ of food grains at subsidized rates with the lowest level of subsidy to APL households and the highest to POP households. The level of subsidy in 2009-2010 was such that APL households could buy wheat at around 40 per cent of the market price, BPL households at around 26 per cent of the market price, and POP households paid about 13 per cent of the market price. Similar figures for rice were 51 per cent, 36 per cent and 19 per cent respectively. ${ }^{3}$ 
The large gaps between the subsidized prices and market prices constitute an incentive for intermediaries in the supply chain (including the fair price shop owner) to illegally divert the subsidized grain to the market and thereby profit from arbitrage. Consequently, a significant part of the allotment ends up on the open market while ration cardholders are turned away with the excuse that the shop is sold out of subsidized grain. In 2004-2005, about 54 per cent of subsidized grain was estimated to be lost in this manner (Jha \& Ramaswami 2012). For 2009-2010, the estimate is 40 per cent (Ramaswami \& Murugkar 2012).

Targeting is a formidable problem in India. As a result, a large number of the poor are excluded from coverage; they are simply not on the list. In addition, a sizeable portion of the eligible poor do not participate in the programme for various reasons such as lacking enough cash to purchase the monthly rations all at once. According to Jha and Ramaswami (2012), only about 30 per cent of the poor derive some benefit from the PDS. ${ }^{4}$

The PDS requires the government (through the FCI) to run the entire system to procure grain, store it and distribute it. The government operations are more costly than the private sector as evidenced by the fact that the market price is a little lower than the 'economic cost' of procuring, storing and transporting it to state government warehouses. ${ }^{5}$

Figure 1 shows the waste and inefficiency of the PDS as calculated in Jha and Ramaswami (2012). Only 10 per cent of the food subsidy

FIGURE 1. Decomposition of Food Subsidy Expenditures

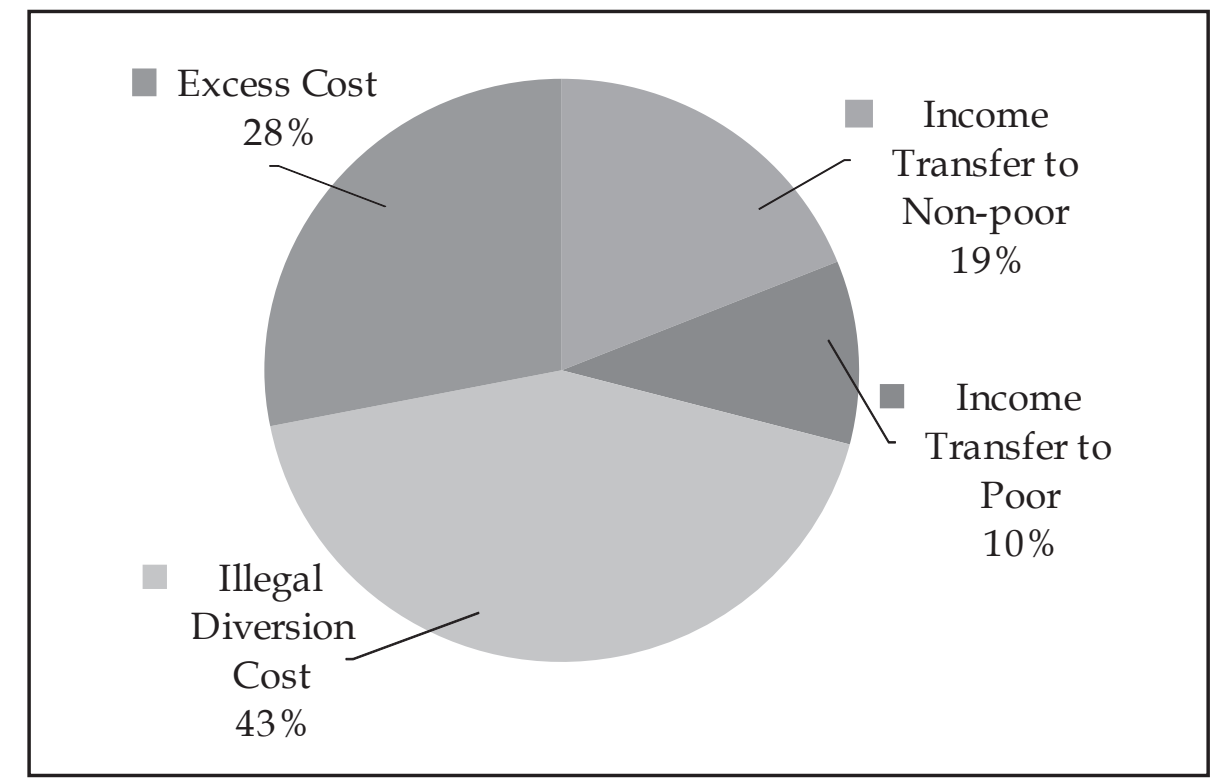

Source: Jha \& Ramaswami (2012) 
expenditure ends up as an income transfer to the poor. Seventy-one per cent of the subsidy expenditure is lost because of corruption and the excess cost of government agencies. Clearly, the PDS is an expensive (and weak) mechanism for income transfer to the poor.

\section{The Influence of the PDS on the Market Prices of Food Grains}

Jha and Ramaswami (2012) estimate that in 2004-2005, about 70 per cent of the poor were excluded from the benefits of the PDS and had no option but to buy grain on the open market. Thus, market prices crucially affect the well-being of the poor. Therefore, in order to be able to assess the impact of the PDS on the welfare of the poor, we also need to understand how the existence of the PDS influences the market prices of food grains.

The government is an overwhelmingly large player in India's grain market. In 2010-2011, the government procured almost half of the marketed surplus (Economic Advisory Council 2011). ${ }^{6}$ It is not difficult to imagine therefore that the behaviour of private traders is heavily influenced by the procurement decisions of the government. To understand this process in detail, let us first see how the grain market functions in India. Since the operations of rice procurement are slightly more complicated than that of wheat procurement, we will illustrate our arguments by examining the wheat market. ${ }^{7}$

The government (through the FCI) is obliged to buy all the grain that anyone wants to sell at the pre-announced support price. After the harvest, the government as well as private traders are in the market procuring grain. As long as the government operations continue, the support

TABLE 1: Support Prices and Procurement: 2001-2002 to 2010-2011

\begin{tabular}{|c|c|c|}
\hline Year & $\begin{array}{c}\text { Minimum Support Price } \\
\text { (in Rs. per quintal) }\end{array}$ & $\begin{array}{c}\text { Amount of Procurement } \\
\text { (Million tons) }\end{array}$ \\
\hline $2001-2002$ & 580 & 20.6 \\
\hline $2002-2003$ & 610 & 19.0 \\
\hline $2003-2004$ & 630 & 15.8 \\
\hline $2004-2005$ & 630 & 16.7 \\
\hline $2005-2006$ & 640 & 14.7 \\
\hline $2006-2007$ & 700 & 9.2 \\
\hline $2007-2008$ & 850 & 11.1 \\
\hline $2008-2009$ & 1,000 & 22.6 \\
\hline $2009-2010$ & 1,080 & 25.3 \\
\hline $2010-2011$ & 1,100 & 22.5 \\
\hline
\end{tabular}

Source: Food Corporation of India - the support prices include the bonus announced for that year. Available from: http://fciweb.nic.in. 
price is the market price. A trader's margins come from the difference between expected future prices and the support price. When the government maintains large stocks, future prices are unpredictable. What if the government offloads its stocks? A feared export ban and other restrictions on private trading activity have similar effects. As a result, private traders withdraw from the market. The government does not have this option and is bound to purchase all that is offered for sale at the support price. The result is that the government procurement (and stocks) increase even more than they would have otherwise (i.e., if the initial level of stocks were low). ${ }^{8}$

Table 1 shows how the support price and the procurement for wheat have moved over the last decade. From 2001-2002 to 2006-2007, the support price increased by 20 per cent. Then things changed dramatically. In 2007-2008, the support price increased by 21 per cent and the following year by another 18 per cent. This is the period during which world food prices peaked. India responded by closing off exports to world markets and by hiking support prices so that it could procure enough to maintain supply to the PDS. Some observers have maintained that the sharp hikes in support prices were populist policies aimed at garnering support from the farm lobby in a parliamentary election year (2009). This fails to explain the modest movement in support prices during the first half of the decade: a period that also saw parliamentary elections (in 2004). The explanation also does not square with the export bans and with the imports of wheat during this period at prices higher than those granted to domestic producers. A more consistent explanation is the government's overriding commitment to the PDS, which in turn derives from the perception that a failure here would be costly electorally.

What is surprising is that this situation has continued until now. Why has the government not undertaken open market sales to bring the price down, especially during this period of inflationary concerns? One plausible explanation is that the government machinery is simply not set up to sell the excess inventory on the open market. To do so, the FCI would have to receive permission from the Food Ministry as well as the Ministry of Finance, especially if they had to sell at less than their 'economic costs', i.e., at a nominal loss. In other words, although 'price stabilization' has been one of their primary objectives, they have no streamlined administrative procedures to sell in a timely manner to achieve it. Over the years, the FCI has been quick to buy but unable to divest itself systematically of unwanted stocks, thus leading to embarrassing high stock levels. 
Thus, the combined effect of excess procurement of grain and the government's inability to dispose of excess stocks results in the unintended consequence of a rise in the market price of food, inflicting pain on the poor who have no choice but to buy on the open market. This leads to hunger amidst abundance. It is a peculiar outcome that while the government focuses on its supply commitments to the PDS, it is not nearly as focused on the consequences of its actions on market prices and on the poor. ${ }^{9}$

An interesting question is, if the government is so committed to the PDS, why has it allowed it to become so dysfunctional? Why doesn't the government put more effort into improving administration and reducing waste and corruption? The answer perhaps lies in the divided responsibility of the central and state governments. The central government feels political pressure to maintain supplies to the PDS. The corruption and waste that impede delivery can possibly be deflected to state governments and local administration.

\section{Implications of the PDS for Farmers}

First, it is important to note that India's domestic food grain market is somewhat shielded from fluctuations in the international market. For example, the international rice price is much higher today than that in the domestic market but the international wheat price is lower than in the domestic market. Indian farmers are protected from the volatility in the international markets but are denied the opportunity to sell on the international markets through export bans. This has been the case throughout India's post-Independence history and it is likely to remain so for the foreseeable future due to the government's commitment to food subsidies.

Food subsidy through the PDS is a big cost item. Food subsidies equal about 1 per cent of India's GDP and about 8.25 per cent of the non-plan expenditure budget of the central government. These numbers may see a quantum jump of 50 per cent in the year 2013 when the National Food Security Bill will be put to vote. If the domestic prices were allowed to fluctuate as much as international prices, the government would have to have a massive reserve fund to accommodate the fluctuations in the budgetary provisions for food subsidies and we suspect that the Finance Ministry is not going to be willing to do it.

\section{Coarse Grain Farmers}

In all discussions of food price policy, it is customary to talk about 'farmers' as if they were one homogenous group with common inter- 
ests. However, in the context of the PDS in India, this is certainly not the case.

The FCI procures wheat, rice and coarse grains (jowar, bajra, maize and ragi) for distribution through the PDS. But the coarse grains are a marginal item in PDS. For example, in 2010, 22.5 million tons of wheat, 34.1 million tons of rice and 0.4 million tons of coarse grains were procured. It is fair to say that PDS is a system to distribute mostly subsidized wheat and rice to the whole country. This keeps domestic prices high for farmers who grow wheat and rice and partially compensates for the government policy to maintain export bans. Out of the total procurement of 22.5 million tons of wheat in 2010, 10.2 million tons were procured from the state of Punjab, 6.3 million tons from Haryana, 3.5 million tons from Madhya Pradesh and 1.6 million tons from Uttar Pradesh. Punjab and Haryana supply the bulk of the PDS requirements for wheat. For rice, the distribution is a little less concentrated. Out of the total procurement of 341 million tons of rice, the state of Andhra Pradesh supplied 90 million tons, Punjab 85 million tons, Uttar Pradesh 40 million tons, Chattisgarh and Orissa 28 million tons each, West Bengal 17 million tons, Haryana 14 million tons and Bihar 10 million tons. The lion's share comes from Andhra Pradesh and Punjab.

In several states such as Karnataka, Maharashtra and Rajasthan, coarse grains are important staples. These coarse grains are typically cultivated in arid areas where the soil is of a low quality; the farmers are poor. When the PDS sells subsidized wheat and rice, it has a dampening effect on the coarse grain prices. Coarse grain farmers in these areas are short-changed by the PDS. Last year over 50,000 farmers from the state of Maharashtra signed a letter to the prime minister requesting a reappraisal of the PDS. This shows that some farmers are not happy with the PDS and that different states have different preferences when it comes to the means of delivering food subsidies. For example, in Maharashtra, where jowar and bajra are main staples, if the FCI finds it unwieldy to procure coarse grains, the state government might prefer to give cash transfers. Consumers could then spend it on their preferred staples, in turn giving a boost to the local farmers. Given the regional diversity in India, this sort of flexibility in government policy is crucial. 


\section{Main Players in the Political Economy of Food Subsidy}

\section{State Governments}

Once a state has received its allotment of grain, it is the state's responsibility to distribute it. While thinking about the political economy of food security, we must consider the state governments' role in determining the outcome.

\section{Right to Food Campaign}

In recent years, the main responsibility for political action on behalf of the poor has been taken up by civil society (i.e., the NGOs). Unhappy with the poor performance of the public distribution system and the lack of political interest, some civil society organizations have pushed to embed food security in the legal framework and secure some degree of state commitment. In 2001, the People's Union of Civil Liberties filed a public interest petition in the Supreme Court of India demanding judicial oversight of the food intervention by individual states. They argued that the right to food derives from the right to life that is guaranteed by the Constitution. The case is still ongoing. However, the Supreme Court has been sympathetic to the petition indicated by the wide range of directives it has issued so far.

An informal network of individuals and organizations has organized around the public interest litigation to campaign for a right to food. The Right to Food campaign has pressed for a range of interventions beyond just food programmes, such as public works programmes, public services for nutrition, health and education for young children, and securing equitable land and forest rights. The willingness of the judiciary to adjudicate on these issues has provided sustenance to this movement.

\section{National Advisory Council}

Since 2005, the Indian parliament has legislated several highly progressive acts (e.g., Mahatma Gandhi National Rural Employment Guarantee Act (2005), Right to Information Act (2005) and Right to Education (2010)), and now it is getting ready to introduce the National Food Security Bill (or the Right to Food Act) in the next parliamentary session. All of these legislative acts were conceived in the National Advisory Council (NAC) set up by the present prime minister to carry out the mandate of the Common Minimum Programme announced by the United Progressive Alliance (UPA) which refers to the present ruling 
coalition at the centre made up of Congress Party and its allies. Sonia Gandhi, who is the president of the Congress Party and the Chair of the National Advisory Council, is widely regarded as the driving force behind the government decisions.

Passage of an act legally requires the government to carry out the act, and NGOs take it upon themselves to make sure that it does. Thus, these acts are created to arm the civil society organizations with tools to hold the government accountable and are a testimony to the new-found power of the civil society. This has been possible because Mrs. Gandhi has invited many high profile social activists to the NAC and they have been driving the agenda. For the first time, the poor have acquired a strong voice in creating legislation. But how has it affected the outcome?

NAC membership has infused Indian policy making with renewed idealism that had eroded over the post-Independence period. However, idealism seldom comes without an ideological bias. The social activists in the NAC have come to believe that the market seldom works in favour of the poor and therefore distrust it. Perhaps their bitter experience with the influence of business interests over government actions and the indifference of the Indian rich toward the plight of the poor have made them deeply suspicious of any market-oriented solution to poverty problems.

\section{Central Government (Cabinet)}

The NAC was created to put forth a progressive social agenda that would reflect the Common Minimum Programme announced by the Congress Party in May 2004. Its mandate is to draft legislation that would reflect the agenda. The operational wing of the government, namely the cabinet and the central bureaucracy, must concern themselves with the practical aspects of the suggested legislative agenda-whether the government has the wherewithal to make it work or the financial resources to do it, and must balance the additional fiscal burden against equally pressing needs. In the specific case of the National Food Security Bill, the government found NAC's recommendations unaffordable. This is understandable as the cost of executing the NAC's draft proposal would have exceeded 2 per cent of India's GDP. In comparison, the total health expenditure by the central and state governments is only about 1 per cent of GDP, and education expenditure is only 3-4 per cent. The Food Security Bill is undoubtedly a costly item and it is easy to see why the government would try to whittle down the recommendations of the NAC. In addition, the government would face logistical and infrastructural problems 
if the total amount of grain to be procured and distributed goes up dramatically. For all these positions, the government position has been more conservative than that of the NAC.

It is important to remember that the sector that has spearheaded India's economic growth over the last two decades has been the information technology (IT) sector. It is one area where Indian industry has shone in international competition. It is not a surprise therefore that the government has come to have some faith in solutions based on IT. Last year the government announced an ambitious scheme to give each willing Indian citizen a Unique Identification number (UID) with biometric identification. This would give some official identity to millions of Indians who have none in this informal economy. It will create direct links between the central government and an individual citizen and thus facilitate direct transfer of resources to individuals and bypass the siphoning off by corrupt officials. The government has appointed an ex-CEO of the software giant Infosys to a position with a cabinet rank to lead this initiative. It is clear that the government is serious about the UID programme. It is a fair guess that the government would be equally serious about any technological solution that UID would facilitate, such as cash transfers.

\section{Fair Price Shopkeepers' Lobby}

It is true that selling subsidized grain on the open market can be a very profitable business and licenses for these fair price shops are a means of patronage by politicians. We can imagine that these shopkeepers would not want to see the PDS replaced by a system of cash transfers or some other alternative. However, this lobby must exert its influence through its internal dealings, which are not observable, and we will therefore not comment further on this lobby.

\section{Debate over the Food Security Bill}

Over the last year or so, there has been a fierce debate in the media over the provisions of the National Food Security Bill. On one side are the social activists associated with the Right to Food campaign, who are also well represented in the NAC. The main demands by the Right to Food campaign activists are: universal or near universal coverage to minimize the exclusion of the truly needy, a continuation of the inkind transfer system through the PDS (albeit a reformed version), and auxiliary programmes such as cooked meals for pregnant women, the destitute and the homeless. 
On the other side of the debate, however, is not the political right who are ideologically opposed to any government transfer programmes; rather, it is mainstream economists and other commentators who are arguing about the means rather than the ends of delivering food subsidies. Even when agreeing with the case for near-universal coverage of a food subsidy system, many economists have observed that it would be a mistake for the government to be bound to the PDS. The staggering inefficiency of the distribution system means that alternatives including cash transfers must be tried. The government (i.e., the Cabinet) does not participate directly in the public debate but makes its presence felt through other means, such as appointing expert committees to review the recommendations of the NAC.

The case for near universal coverage is logically sound. In an informal economy such as India's, it is far easier to identify the well-to-do than the poor. Also, when 78 per cent of the population lives under US\$2 a day at purchasing power parity (PPP), it is hardly worth sorting out who is under US $\$ 1$ a day (that is, the BPL population) and who is above. The only reason that the government has balked at conceding the near universal coverage is the cost and procurement difficulties that it cannot handle. This is especially so if the subsidy has to be delivered through the cumbersome and wasteful vehicle of the PDS. In some ways, the insistence of the social activists to continue with in-kind transfers has turned out to be counter-productive to its demand of universal or near universal coverage to minimize the exclusion of the truly needy.

The NAC floated its first draft proposal, which stopped short of near universal coverage and recommended 75 per cent coverage with $35 \mathrm{kgs}$ to each BPL household at 2 rupees (Rs.) per $\mathrm{kg}$ for wheat and Rs. 3 per $\mathrm{kg}$ for rice. The government set up an expert committee to assess the NAC recommendations. The committee had among its members the principal economic advisor to the central government as well as some prominent civil servants. The committee recommended that the coverage be reduced from 75 per cent to 46 per cent and cited procurement difficulties and cost. The Expert Committee also mentioned alternatives to the PDS such as smart cards, food stamps or cash transfers as something to strive for in the future, although the suggestion was thrown in almost as an afterthought. Though the committee report's arguments and its calculations of costs were based on the assumption that food subsidies would be delivered through the PDS, the offhand comment about cash transfers evoked a rebuke from the Right to Food activists (Hindu, 3 August 2011). The reduction of coverage was criticized not 
only by the activists but also more neutral commentators and academics (Indian Express, 19 January 2011; Hindustan Times, 29 February 2012) who argued that the coverage would not have to be reduced if the costly PDS were replaced by cash transfers or some other alternative.

At this point, the NAC invited feedback from the public on their draft and indeed there was some debate in the public media on both issues - the coverage and whether cash transfers should replace in-kind transfers. A group of scholars sympathetic to the Right to Food campaign argued that a few experiments to reform the PDS were showing signs of success and it would be a mistake to replace the PDS with an untried system of cash transfers (Ghosh 2011; Khera 2011). The debate was joined by other economists who felt that cash transfers deserved a chance (Kotwal, Murugkar \& Ramaswami 2011; Roy Chaudhuri \& Somanathan 2011). Two examples of successful reforms were in the states of Chattisgarh and Tamil Nadu. In both cases, the coverage was near universal and IT was used to trace every shipment of grain from a warehouse to a designated shop so that any diversion could be detected. There was also an emphasis on using community awareness to watch for local corruption, for example through social audits. In fact, organizing the local community to check corruption is what appeals philosophically to the Right to Food group.

One significant entry into the debate was an open letter to Mrs. Gandhi signed by 45 Indian economists, in India as well as abroad, urging that coverage be kept near universal and not to preclude experiments with alternatives to the PDS (Economic Times 2011a). Their argument was based on the fact that India was a large and diverse country and if each state can experiment with a system that suits them best, good solutions would evolve. In the meantime, the state of Bihar has already started pilot projects using cash transfers. Their BPL count exceeds that of the central government and this extra subsidy comes from Bihar's own resources. This allows them some latitude to experiment.

There are several things about a switch to cash transfers that worries the Right to Food group. They believe that the technological infrastructure necessitated by cash transfers would be attractive to the corporate sector and government policy would be hijacked. They also believe that the poor would be short-changed by a switch to cash transfers as the government would not change the amount of the cash subsidy in response to a change in grain prices. As a larger philosophical issue, they prefer solutions to social problems based on collective action by the local community rather than technological solutions, as shown by 
their opposition to the UID project. We will discuss this in the next section.

The NAC came back with a final draft four months later that did not deviate much from their preliminary draft in terms of the coverage and insistence on the PDS. The draft did not mention alternatives to the PDS and left little scope for states to experiment. The open letter to Mrs. Gandhi did not seem to have had any impact on the NAC. The draft recommended supervision even over tasks that were the responsibilities of state governments. The draft also contained vague and uncontroversial recommendations to improve agricultural productivity, which had not figured in the debate.

The NAC draft was handed over to the Expert Committee of Ministers, a sub-committee of the Cabinet, which modified the NAC draft. The revised draft raised another storm of protests from the Right to Food group. Predictably, the government reduced the coverage from the level recommended by the NAC and introduced the possibility of cash transfers. The government was not only going to allow experiments with cash transfers but was recommending it at a later date. The mention of cash transfers has agitated Right to Food campaigners. They fear the government will force the states to switch to cash transfers prematurely, wasting the progress made in reforming the PDS.

\section{Present Version of the National Food Security Bill}

On 22 December 2011, the National Food Security Bill was introduced in the parliament. Instead of talking in terms of BPL and APL groups, it uses a new language of 'priority' and 'general' categories. It does not specify clear criteria for what constitutes these two categories but prescribes 'not less than 46 per cent of the rural and 28 per cent of the urban population shall be designated priority households'; the combined coverage of priority and general households shall be 75 per cent of the rural population and 50 per cent of the urban population. The PDS issue prices are specified as Rs. 3/2/1 for rice/wheat/millets (actually called 'coarse grains' in the bill) for priority households, and not more than half of the minimum support price for general households. In addition, there are special provisions for children, pregnant women, as well as lactating mothers.

The issue of whether the food subsidy should be delivered as cash or kind is left vague, perhaps quite deliberately. In one short section of the bill (section 7), called 'PDS Reforms', the bill states that central and state governments 'shall endeavour to progressively undertake' various PDS reforms, including: computerization; leveraging 'Aadhaar' (UID) for 
unique identification and proper targeting; full transparency of records; preference to public institutions or bodies in licensing of fair price shops; management of fair price shops by women or their collectives; diversification of commodities distributed under the PDS; full transparency of records; and 'introducing schemes such as cash transfer, food coupons or other schemes to the targeted beneficiaries in lieu of their foodgrain entitlements' as prescribed by the central government.

Thus, cash transfers are mentioned as a kind of reform. But the whole bill, including the obligations of the central government, is written in terms of the amounts of grain. This is quite problematic as one can imagine the possibility of a legal challenge in the future if a state opts for cash transfers (Economic Times 2011b; Hindustan Times 2012).

As for the reactions to the bill from the opposite sides of the debate, both sides are resigned to the idea that the government is not going to agree to increasing its fiscal burden. No modification of the bill being urged at this stage requires the government to increase its outlay much more than the allocations in the present draft of the bill. However, many critics on the right who had been silent throughout the debate have now started voicing anxiety over the fiscal burden (Economic Times 2011c; First Post 2011; Indian Express 2012). A common theme has been that there is far too much leakage and corruption in all government schemes and given that, the huge expenditure on food subsidies is wasteful. The result of this expression of fiscal anxiety in the media has been greater focus in the public debate on the efficiency of the methods of implementation.

Among the active participants in the debate on the bill, both sidesthose who favour cash transfers and those opposed to the idea of cash transfers - have now formed a united front in opposing the idea of trying to identify two categories of the poor, 'general' and 'priority'. As the bill stands now, the state governments will engage in this identifying exercise according to the guidelines laid out by the central government. No clear criteria are laid out in the bill itself. There is consensus among the active participants in the debate on the provisions in the bill that, given the failure of targeting under the present system, it is futile to try the same again under the new system. They suggest that instead of differentiating among the poor in two categories, treat them as one group and divide the total allotment equally among them. In other words, the idea is to identify the more easily identifiable group - the non-poor - that is, the top 25 per cent who would be excluded from any subsidy, and spread the subsidy equally among the rest. What this 
would mean is that the households that get classified as the priority sector and would have received $35 \mathrm{kgs}$ of grain per household would then receive only $25 \mathrm{kgs}$ of grain. Of course, the households classified as the general sector would receive $25 \mathrm{kgs}$ instead of $15 \mathrm{kgs}$. On paper, this looks like short-changing the poorest. However, in practice, there is no targeting system in India that would correctly differentiate between the poorest and the slightly less poor. When three-quarters of Indians live on less than US $\$ 2$ a day, it is hard to argue that those under the general category do not need a food subsidy. It is clearly wasteful to engage in this exercise of identifying different levels of poverty. This logic united both sides of the debate in organizing another joint letter to the prime minister urging him to scrap these two categories and to simplify the exercise of targeting (Economic Times 2012). It remains to be seen whether the government modifies the bill accordingly.

It is curious that when the logic for extinguishing the two categories appears so compelling, the government would still have this sort of targeting in the draft of the bill that it introduced in the parliament. There seems to be a perception that the Congress Party strategists are worried that the Bharatiya Janata Party (BJP), the opposition party, would exploit the fact that the government has betrayed the promise to the poorest by reducing their subsidized allocation from $35 \mathrm{kgs}$ to $25 \mathrm{kgs}$ per household. Somehow there is no accounting here that in the bargain many households who would have received only $15 \mathrm{kgs}$ per households would now receive $25 \mathrm{kgs}$ per household. Also, simplifying the targeting mechanism would reduce the exclusion error substantially and would incline a chunk of the electorate to vote for the ruling party. Two things about Indian politics are revealed by this perception that a seeming betrayal of the promise on paper would be politically more costly than the certainty of bad implementation later. They are, first, the short term is deemed more important than the long term, and second, tokenism has more currency than performance. However, it is possible that the voters' expectations are changing and that they are becoming more demanding in terms of performance; and if so, it would be a grave political miscalculation for the government not to simplify the bill to ensure better implementation.

The most serious political problem for the bill is likely to be strong opposition by state governments. The central government obligation is to provide the resources to the state governments and after that, delivery and distribution issues are all presumed to be the responsibility of the state governments. The central government specifies the number of 
poor in two different categories in each state as well as the criteria for identification in each category, and yet, identifying the households in each category is the responsibility of the state governments. In short, the decision-making is highly centralized and is divorced from the agency that would implement the decisions.

As one would expect, there is a great deal of variation in bureaucratic competence, social capital, the extent of poverty and the level of corruption across the country. What works in Tamil Nadu may not work in Bihar and vice-versa. It is not surprising therefore that several states that have already embarked upon experiments with different ways of delivering the food subsidy have protested against the idea that the central government could dictate the details of how to deliver the food subsidy. Moreover, some states (e.g., Tamil Nadu, Bihar and West Bengal) have protested that the central government has assumed the authority to specify the coverage. The central government, of course, has no objection to the states widening the coverage as long as they use their own resources for the extra coverage.

A good solution for a possible impasse between the centre and the states is to allow the states to devise their own delivery mechanisms as long as they do not ask for extra resources from the centre. Dictates by the centre would be rejected by the states but the central government would certainly assert its right to determine the amount of resources it devotes to the food subsidy. We believe that finally when the dust settles, the outcome will be state flexibility in choosing the delivery mechanism within the budget allotted by the centre.

We will speculate on what we see as the future of food security in India. But first we should discuss the role of community, an argument that has influenced this debate.

\section{Role of Community}

As mentioned before, many (though not all) civil society activists have come to put their faith in the community to check local corruption. This is partly because they have lost faith in the ability and willingness of the government bureaucracy to police itself. At the same time, they want to stay away from technological solutions to resolving social problems. In part, this comes from deep suspicion of the profit-motivated corporate sector that would be the supplier of the technology, and in part from a basic belief in small village communities governing themselves as an ideal to strive for in a true democracy. It is on this romantic notion of the self-governing village community that we would like to comment. 
India is a very diverse country. Social dynamics differ in different states. A recent study conducted in Maharashtra (Anderson, Francois \& Kotwal 2011), based on a survey of 9,000 households from 300 villages, would cast a shadow on one's faith in the ability of local communities to help themselves. It shows that despite all the indicators signalling a well-functioning village democracy, the local elites run the village in their own interests. Poverty alleviation schemes are blocked and wages are kept low through long-standing patron-client relationships. Traditional hierarchical structures are manifested through modern formal democratic structures, sabotaging the progressive schemes of the central government. Farm workers and small farmers are beholden to the highcaste (Maratha) farmers as they take consumption contingency loans and get access to Maratha-dominated trader networks. It makes them political allies of the Maratha farmers in the village elections enabling the traditional hierarchies to continue to hold sway. It is difficult to imagine, under these circumstances, how a community will check local corruption through social audits and community spirit.

Not all civil society groups have this faith in local communities. Ashwini Kulkarni, the Director of an NGO active in rural Maharashtra called Pragati Abhiyan (Indian Express, 15 August 2009), has argued very persuasively that what we need is a well-designed management system with appropriate use of information technology. She believes that the behaviour of villagers as well as the bureaucrats is very much dependent on the detection and enforcement mechanisms that exist in the system. While doing a comparative study of the implementation of the Mahatma Gandhi National Rural Employment Guarantee Act programmes in Maharashtra and Andhra Pradesh, she found that the key to understanding the vastly superior performance in Andhra Pradesh was the superior management system and an appropriate use of IT to streamline wage payments in Andhra Pradesh. She believes that the community behaviour is different in the two states as a result.

How effective community organization would be will vary across different communities and different states. It would be a mistake to take that as a generic solution. The use of better management systems and information technology cannot help but improve the outcomes once a certain minimum level of infrastructure becomes available. 


\section{The Future}

Given the main players in the food security debate, and given the situation at present, what course should we realistically expect on India's food security front? We feel that one significant player that has provided the ideological platform to launch the food security bill, namely the NAC, will find its influence coming to an end as the bill has been introduced in the parliament. On the other hand, the state governments that have been fairly dormant so far are likely to flex their muscles and try to get some of the draconian restrictions that the present draft has placed on their freedom relaxed. It is not likely that the central government will budge on their allotment of Rs. 945 million for the total food subsidy bill. Any adjustments that the government agrees to will most likely have to fit in this overall budget. For example, if the government agrees to increase the coverage, they may do it while reducing the per person subsidy.

The central government is committed to the UID project; it is one of their 'blue chip' projects and they regard it as their legacy. The project will not have served its purpose unless it can be used to disburse benefits such as food subsidies. This makes us believe that at some point once the infrastructure is in place, cash transfers will arrive perhaps not simultaneously across India, but in a trickle. A state like Bihar that is already keen on switching to cash transfers will try it out first and if the experiment is a success, it will be replicated elsewhere.

As far as farmers are concerned, we do not envisage export bans being lifted because international prices do fluctuate a lot and the government will be reluctant to let the spikes in the international prices disrupt their budget plans. Thus, even if cash transfers arrive, it is unlikely that the government will allow international prices to dictate domestic prices in India as the food subsidy is such a large part of the government budget.

The key development for food security is, in fact, improvements in agricultural productivity, and yet, this has been conspicuous by its absence in the debate. We are afraid that this most important driver of poverty will remain as a non-controversial suggestion in every draft and will not be followed up, thus jeopardizing all future arrangements to eliminate poverty.

Ashok Kotwal is a professor in the Department of Economics at the University of British Columbia. Milind Murugkar works with Pragati Abhiyan, a nongovernmental organization in the Indian state of Maharashtra. Bharat Ramaswami is a professor in the Planning Unit of the Indian Statistical Institute in Delhi. 


\section{NOTES}

1 This is not to say that there are no doubts or scepticism about welfare programmes. For instance, politicians have been concerned about the impact of public works projects (which are undertaken under the employment guarantee act) on the availability of farm labour. Similarly, there are apprehensions about the cost of the food security bill. Neither of these reservations questions the need for welfare programmes.

2 Here we will focus only on food grains as they are the main food items and constitute the central issues in the food security debate, although other items such as sugar, edible oil and kerosene are also available in the fair price shops.

3 These figures are derived from Table 1 of Ramaswami and Murugkar (2012).

4 Jha and Ramaswami (2012) examine the workings of the PDS in India based on the data in the Consumption Expenditure schedule of the 61st round (2004-2005) of the National Sample Survey.

5 For a detailed discussion of this point, see Jha and Ramaswami (2012).

6 At the height of the socialist rhetoric in India's polity, the government attempted to nationalize the wheat trade in 1974 - an experiment that failed spectacularly.

7 Rice is sold as paddy that gets processed into rice at the rice mills. What the government announces is the Minimum Support Price (MSP) for paddy and not for rice. Also, the rice mills pay a levy. Wheat marketing is relatively simple. What the consumers buy in the market is what the farmers sell to the traders or to the government and that is what the MSP is announced for.

8 For a formal account of the process, see Balakrishnan and Ramaswami (1995).

9 In this context, Kotwal, Murugkar and Ramaswami (2011) observe the following: 'Since the 1990s, with the exception of a single year, the government has bought more grain than it has sold through the PDS. Of course, the politics around the procurement price is a proximate reason. But there are other reasons too: most notably government miscalculation. At the higher levels of the government, there is immense paranoia about food shortages affecting the PDS. Politicians and bureaucrats perceive the costs of insufficient supplies but nobody is held accountable for excessive stocks and high prices. Predictably, the errors are in one direction.... Private trade will be displaced and so excess stocks in any one year continue to the next unless the cycle is broken by an exceptional event such as a drought'.

\section{REFERENCES}

Anderson, S., P. Francois and A. Kotwal. 2011. 'One Kind of Democracy'. University of British Columbia (mimeo).

Balakrishnan, P., and B. Ramaswami. 1995. 'Public Intervention and Private Speculation: The Case of Wheat Procurement'. Journal of Quantitative Economics 11(2): 59-83.

Banerjee, A., and E. Duflo. 2007. 'The Economic Lives of the Poor' Journal of Economic Perspectives 21(1): 141-167.

Banerjee, A., and E. Duflo. 2011. Poor Economics. New York: Public Affairs.

Deaton, A., and J. Dreze. 2009. 'Food and Nutrition in India: Facts and Interpretations'. Economic and Political Weekly 44(7): 42-65.

Economic Advisory Council. 2011. 'Report of the Expert Committee on National Food Security Bill'. New Delhi: Government of India. Available from: http:// eac.gov. in/reports/rep_NFSB.pdf. 
Economic Times. 2011a. 'Food Security Act: Economists letter to Sonia Gandhi', 31 May.

Economic Times. 2011b. 'Sleepwalking into a Quagmire: The Present Course of the Food Bill', 13 December.

Economic Times. 2011c. 'Food Security Bill: Can We Afford Rs. 6 lakh cr Food Subsidy in 3 Years?' 17 December.

Economic Times. 2012. 'Food Security Bill: A Simple Proposal', 12 March.

Eswaran, M., A. Kotwal, B. Ramaswami, and W. Wadhwa. 2009. 'Sectoral Labour Flows and Agricultural Wages in India, 1982-2004: Has Growth Trickled Down?' Economic and Political Weekly 44(2): 46-55.

First Post. 2011. 'It is Not About Feeding the Poor', 20 December.

Ghosh, J. 2011. 'Cash Transfers as the Silver Bullet for Poverty Reduction: A Special Note'. Economic and Political Weekly 56(21): 67-71.

Hindu. 2011. 'PDS: Signs of Revival', 11 June.

Hindu. 2011. 'Right to Food Campaign Calls for Action Against Draft Food Bill', 3 August.

Hindustan Times. 2012. 'It Simply Can't Fail', 29 February.

Indian Express. 2009. 'Whose Right is it Anyway?', 15 August.

Indian Express. 2011. 'Don't Water Down Food Security', 19 January.

Indian Express. 2012. 'Last Straw on the Fiscal Back', 16 February.

Jha, S., and B. Ramaswami. 2012. 'The Percolation of Public Expenditures: Food Subsidies in India and the Philippines'. Forthcoming, India Policy Forum.

Khera, R. 2011. 'Trends in Diversion of Grain from the Public Distribution System'. Economic and Political Weekly 56(21): 106-114.

Kotwal, A., B. Ramaswami, and W. Wadhwa. 2011. 'Economic Liberalization and Indian Economic Growth: What is the Evidence?' Journal of Economic Literature 49(4): 1152-1199.

Kotwal, A., M. Murugkar, and B. Ramaswami. 2011. 'PDS Forever?' Economic and Political Weekly 56(21): 72-76.

Patnaik, Utsa. 2007. 'Neo-liberalism and Rural Poverty in India'. Economic and Political Weekly 42(30): 3132-3150.

Patnaik, Utsa. 2010. 'A Critical Look at Some Propositions on Consumption and Poverty'. Economic and Political Weekly 45(6): 74-80.

Paul, S. 2011. Essays on Economic Development, PhD Thesis, University of British Columbia.

Ramaswami, B., and M. Murugkar. 2012. 'Food Policy Reforms: A Rapid Tour of Possibilities'. New Delhi: Asian Development Bank. (Mimeo)

Roy Chaudhuri, A. and E. Somanathan. 2011. 'Impact of Biometric Identification-Based Transfers'. Economic and Political Weekly 56(21): 77-79. 